TITLE:

\title{
cDNA cloning and expression of bovine endothelin converting enzyme(Abstract_要旨)
}

$\operatorname{AUTHOR}(\mathrm{S})$ :

Ikura, Takeshi

CITATION:

Ikura, Takeshi. cDNA cloning and expression of bovine endothelin converting enzyme. 京 都大学, 1997, 博士(医学)

ISSUE DATE:

1997-03-24

URL:

http://hdl.handle.net/2433/202206

RIGHT: 


\begin{tabular}{|c|c|}
\hline 氏 & $\begin{array}{lll}\text { い } & \text { くら } & \text { た倉 毅し } \\
\text { 刑 }\end{array}$ \\
\hline 学位 (専攻分野) & 士（医学） \\
\hline 学位記 番号 & 医 博 第 1889 号 \\
\hline 学位授与の日付 & 平成 9 年 3 月 24 日 \\
\hline 学位授与の要件 & 学位規則第 4 条第 1 項該当 \\
\hline 研究科 · 専攻 & 医学研究科外科系専攻 \\
\hline 学位論文題目 & $\begin{array}{l}\text { cDNA cloning and expression of bovine endothelin converting } \\
\text { enzyme }\end{array}$ \\
\hline
\end{tabular}

（牛エンドセリン変換酵素の cDNA クローニングとその発現）

論文調查委員 教授)成宮 周 教 授中西重忠 教 授 飯塚忠彦

\section{論文内容 の 要 旨}

血管系のホメオスタシスの調節には，近年，血管内皮細胞の機能が重要な役割を果たしていることが明 らかになってきている。血管を構成するさまざまな細胞は血球細胞を含めて，互いに液性因子，接着因子 を通じて相互作用しているが，血管内皮細胞が主体となって他の細胞の機能を積極的にコントロールして いることが明らかになりつつある。特に血管のトーヌスの調節を行なう重要な因子として弛緩作用を有す る Nitric Oxide(N0)，収縮作用を有するエンドセリン（ET-1）がある。

ET-1 はその前駆体である preproET-1 がまず 2 カ所で切断され, bigET-1 とよぶ中間体が作られ，さ らにbigET-1の21番目のトリプトファンと 22 番目のバリンとの間でエンドセリン変換酵素により切断さ れ活性型の ET-1 になる。ET-1 はりガンド依存性にその発現が調節される regulated pathwayの分泌様 式をとらず，常に分泌状態にある constitutive pathwayという分泌様式をとる。従ってその発現調節は工 ンドセリン前駆体の preproET-1 の遺伝子発現，あるいはECEの発現調節に依存していることになる。 したがって ECE の構造および機能を明らかにすることは非常に重要である。

$\mathrm{ECE}$ の構造決定のために，ECEcDNAの発現クローニング法を開発した。ECE 活性を持たない CHO-K1 細胞に, preproET-1 遺伝子を導入し, big ET-1 を恒常的に産生する細胞株が樹立された。ウ シ血管内皮より作製した発現ベクターライブラリーを導入後, 抗 ET-1 抗体を結合した赤血球の溶血反応 でET-1を産生する単一細胞が同定された。

クローニングしたウシ内皮型 ECE の cDNA の塩基配列から予想されるアミノ酸配列は N 端に膜貫通 部位をもち，さらに金属プロテアーゼに共通してみられる亜鉛結合領域をもつことがわかった。この構造 は ECE の生化学特徴と一致した。またほぼ同時期に構造決定されたラット ECEの今回クローニングさ れたウシ ECEのアミノ酸配列を比較すると約 $91 \%$ identity を示し, 生化学的な酵素活性部位と考えら れる亜鉛結合領域および膜貫通領域は完全に保存されていることがわかった。ただ活性とは関係のないと 考えられる N 端細胞内領域では相同性が低かった。 
ノーザンブロット解析の結果は, 発現の程度に違いがあるがさまざまな臓器で発現しており, 特に肺お よび心蔵にその発現が多くみられた。つぎにクローン化したウシ内皮型 ECEが in vivoで活性をもつか どうかの検討が成された。 ECE 活性のない C HO-K1 細胞に ECEcDNA を co-transfection しその培養 上清中の immunoreactive-ET を測定した。その結果, CHO-K1 細胞は ECE の cDNA を co-transcection したときのみ ET-1 を産生した。また金属プロテアーゼ阻害剤であるホスホラミドンはこの ECEの cDNAに依存した ET-1 産生を阻害した。したがって今回クローニングした cDNA は実際に細胞レベル でECEとして働いていることがわかった。さらに遺伝子構造が明らかにされ，そのゲノム断片をプロー ブとし，間期染色体に対し，蛍光 in situハブリダイゼーションにより ECE 遺伝子はヒト染色体，1p36.1 に位置することがあきらかになった。

\section{論文審査の結果の要旨}

培養内皮細胞上清から単離，クローニングされたエンドセリン（ET-1）は血管収縮因子として作用し， その分泌様式は constitutive pathwayによると考えられる。

その生合成は前駆体である preproET-1 がまず 2 カ所で切断され, bigET-1 とよぶ中間体が作られ， さらにbigET-1 の21番目のトリプトファンと22番目のバリンとの間でエンドセリン変換酵素により切断 され活性型の ET-1 になる。この bigET-1 から ETへの processing はETに特異的である。

今回クローニングしたウシ内皮型 ECE の cDNA の塩基配列から予想されるアミノ酸配列は $\mathrm{N}$ 端に膜 貫通部位をもち，さらに金属プロテアーゼに共通してみられる亜鉛結合領域をもつことがわかった。また クローン化したウシ内皮型 ECE が活性をもつことを CHO-K1 細胞において確認した。

さらに遺伝子構造を明らかにし，ECE 遺伝子はヒト染色体，1p36.1に位置することが明らかとなった。 以上の研究は ET-1の分泌調節機序の解明に貢献し, また将来 ECE 阻害薬の開発などにより脳虚血や 心筋梗塞の治療薬としての臨床的意義が期待される。

したがって, 本論文は博士 (医学) の学位論文として価值あるものと認める。

なお，本学位授与申請者は，平成 9 年 2 月 24 日実施の論文内容とそれに関連した試問を受け, 合格と認 められたものである。 